\title{
Cargo System, Religion, and Debates of Community Inclusion in a Mexican Nahua Village
}

\author{
György Szeljak \\ America Collections of the Museum of Ethnography, Budapest
}

\begin{abstract}
The case study presents certain aspects of modernization and cultural changes in a small Nahua Indian village in Mexico. It investigates the local cargo system and its religious background; analyses the emergence of protestant denominations and its impact on the cargo system. Debates about locality, inclusion and exclusion, and the symbolic borders of the community are also discussed. The study is based on fieldwork conducted in the Huasteca hidalguense during the period 1996 and 2002.
\end{abstract}

Keywords: Mexico, La Huasteca, Nahuas, cargo system, civil-religious hierarchy, religion, Protestantism, modernization

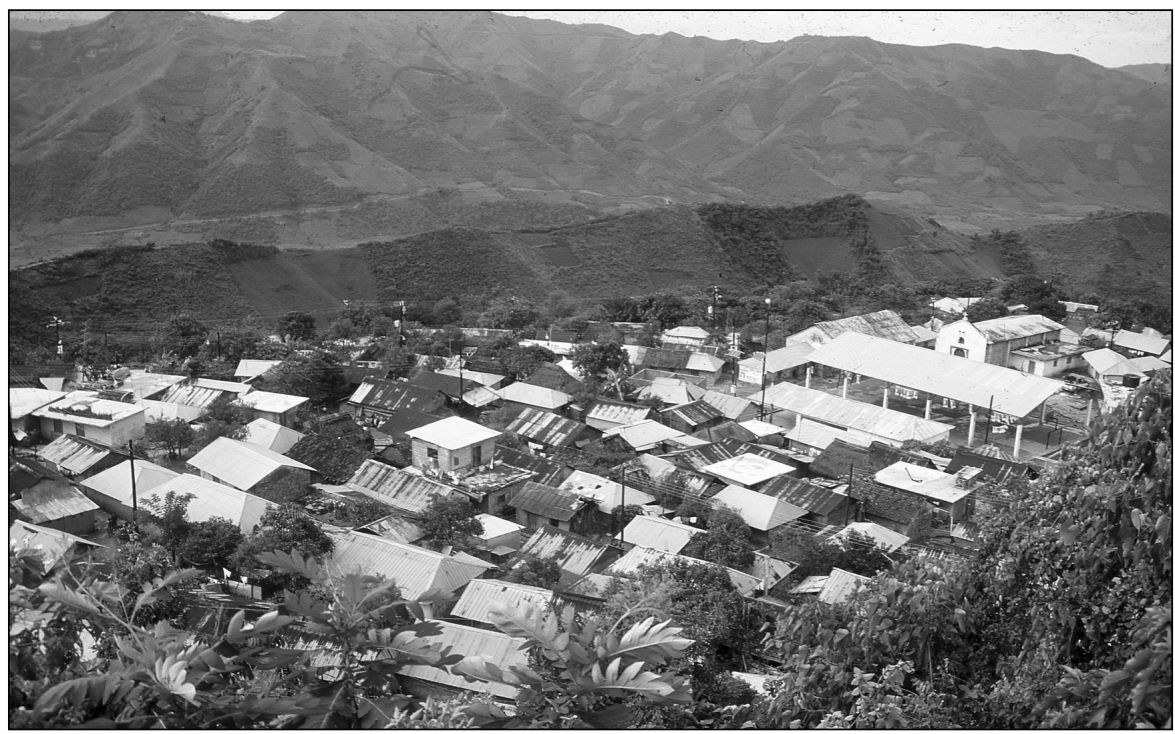

Figure 1. The village of San Pedro de Pachiquitla, Mexico, 2002. (Photo by György Szeljak) 


\section{INTRODUCTION ${ }^{1}$}

Between 1996 and 2002, I conducted extended fieldwork on three occasions in the Huasteca Hidalguense area of Mexico, in the Indian villages nestled among the Sierra Madre Oriental mountain ranges, mostly in San Pedro Pachiquitla. During my stay there, the village of about 1,200 Nahua farmers was just at the beginning of a modernization process: migration into cities has started, subsistence farming was being augmented by income received through migrant work, medical care was more available locally, representatives of New Protestant churches have arrived, and the Mexican political parties also increased their influence among the Indians living there. In this process of change, one of the distinctive elements of the multifaceted discourse about locality, inclusion and exclusion, and the symbolic boundaries of the village was the status of the cargo system which defined important aspects of community belonging as well as the village's traditional ethos. Without being comprehensive, this study presents a few of the religious elements of the debates surrounding this system. ${ }^{2}$

\section{ON THE MESOAMERICAN CARGO SYSTEM}

The system of political and religious institutions in Mesoamerican Indian communities is based on a specific system of officials (or cargo system, sistema de cargos), whose structure is based on the so-called political-religious hierarchy (jerarquía civico-religiosa). The system, which followed Pre-Hispanic patterns and became widespread in the colonial era (CARRASCO 1976), and which has undergone a significant transformation in the $19^{\text {th }}$ century ${ }^{3}$ and continues to adjust to social changes even today, serves to institutionalize the individual's role in the community. Political officials are responsible for the management and administration of the community, for arbitration within the village, and for maintaining relations with mainstream society. Religious officials organize public Catholic celebrations, secure the financial background for certain celebrations, and care for sacred community spaces.

In this particular system, all able-bodied, adult, married men must assume a role. Younger men are initially assigned to lower caliber and thus less prestigious offices. In later stages of life they may assume progressively more important positions (which involve increasingly more time and financial investment), and may get to the positions of village chief or judge - although the pyramid-like system does not make this available to everyone - and then get into the Council of Elders. After fulfilling the duties of each office, a certain number of

\footnotetext{
${ }^{1}$ This study is dedicated to András A. Gergely, one of the most unselfish and helpful people I have ever known, with gratitude for professional support and friendly conversations. I am also immensely grateful to Jesús Ruvalcaba Mercado, Manuel Pérez Zevallos and the inhabitants of Pachiquitla. A version of the study was published in Hungarian: SzELJAK 2013:215-229.

2 See further discussion of this topic, e.g., SzeljaK 2000; 2008; SzeljaK - Van't Hooft 2008.

${ }^{3}$ After the establishment of independent Mexico's public administration, the cabildo indigena, a colonial Indian council that served as a collective regional representation of Indians, lost its legitimacy and was limited to individual villages; and after religious corporations were banned in 1857 , the cofradias slowly disappeared, too, so the organizing of Catholic celebrations became the responsibility of the cargo system within each village. For an analysis of this historical process on the scene of the study, see: CARRERA 2007.
} 


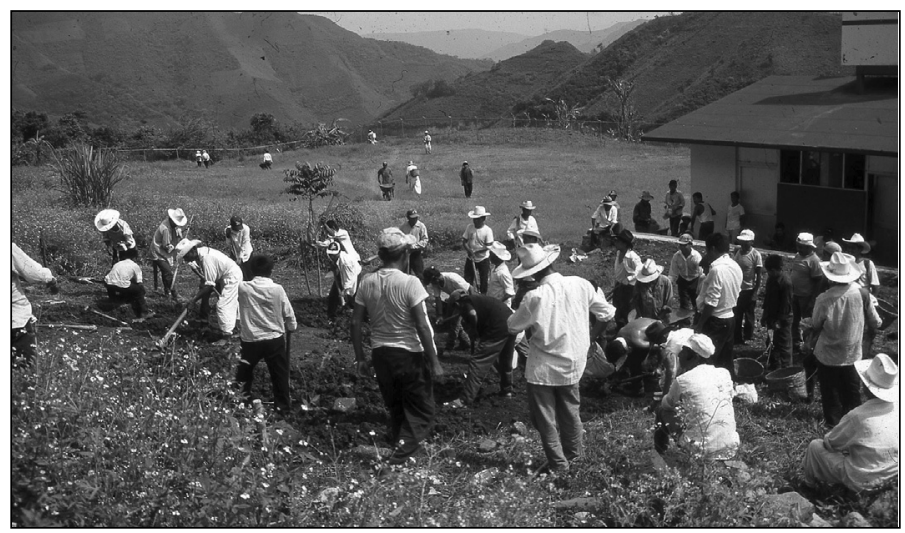

Figure 2. Community work (faena), Pachiquitla, 1996. (Photo by György Szeljak)

rest years follow, depending on the number of community members. The position - unlike positions in the state administrative system - does not come with a salary, and the officials contribute to the management of the community with their time, energy, and in certain posts even with the distribution of a portion of their material possessions.

This system links the Indian villages to the state administration, and the local Catholic cults to the Mexican Catholic Church. Through the functioning of this institution, the communities appear as independent units within the state, and decisions concerning the internal affairs of the village are made on the basis of their own traditions, their own legal customs - even if they occasionally contradict state laws and political intentions. ${ }^{4}$ From a religious point of view, this sovereignty is most helpful in preserving rituals based on the cult of saints but saturated with Pre-Hispanic religious notions - even if the official representatives of the Catholic Church sometimes see it as a divergence caused by superficial evangelizing.

The system is also part of the community's protective mechanism, conservative and "traditional" in nature. The community - or its more influential members - often try to interpret and control the social changes associated with modernization and integration with the nation-state through the operation of this institution. ${ }^{5}$

As for its historical development and internal functions, the system may vary in many ways in certain parts of Mesoamerica. The differences may be prompted, among others, by economic and demographic factors, proximity to larger cities, the ethnic and religious structure of communities, as well as different degrees of modernization or migration. ${ }^{6}$

\footnotetext{
${ }^{4}$ For the common laws of Indian villages, see, for example: CHENAUT - SierRa 1995; ConTreras 2008.

${ }^{5}$ It is no coincidence that in the middle of the $20^{\text {th }}$ century, a number of pro-integration indigenist thinkers (e.g., Aguirre Beltrán) saw this local government structure as an obstacle to development and modernization, while according to turn of the century movements that demanded autonomy, it is one of the most important foundations of ethnic identity, which helps Indian communities preserve their language, common laws and traditions.

${ }^{6}$ Of the extensive anthropological literature on the peculiarities of the Mesoamerican cargo system, see, for example: Cámara 1952; Cancian 1976; Dow 1990; Dow - StePhen 1990; Friedlander 1982; GREENBERG 1981; SANDOVAL et al. 2002.
} 


\section{THE CARGO SYSTEM IN PACHIQUITLA}

In a village that was largely isolated from mainstream society - as was Pachiquitla until the 1980s - the criteria of community belonging were unambiguous. These included continuous residence, land ownership for men, a largely self-sufficient way of life, women marrying within the village, the performance of local religious community rites called kostumbre which combined Pre-Hispanic and Catholic elements (SzELJAK 1997; 2003; 2008), the adoption of the legal customs of the village, as well as participating in the cargo system and, until the age of sixty, in the weekly communal labor. Of the above criteria, this study analyzes the relationship between religion and the cargo system. ${ }^{7}$

In Pachiquitla, the cargo system is based on a hierarchical structure in which, by law, all married, able-bodied adult male residents of Pachiquitla must fill an office in their lifetime. Because of the demographic explosion of the last three decades, however, this is de facto becoming increasingly difficult. Filling the offices is mandatory, and community members are under constant pressure and their participation is verified. Only those suffering from serious physical or mental illness and single or widowed men can get an exemption. Only a man who is willing to take on these tasks has the right to be an equal member of the community, get housing plots and arable land, build a house there, care for his children and school them in the village, and eventually rest in the cemetery. Each office can be held only once, and the majority of appointments last one year.

Thus, the system is built primarily on men; women's duties - with the exception of the Women's Health Committee, formed in 1990 - are not institutionalized, and their involvement is primarily as their husband's aides. Young boys are entered into the community registry at the age of eighteen as "privileged residents of the village," and - if they do not leave for work in the city - they may already take an office. The community does not have a traditional religious rite of passage that symbolically marks a man's transition into adulthood, therefore participation in the cargo system and commencing communal labor are the public representations of this, and each individual position becomes an important reference point for each stage of life (SZELJAK 2000:119-122).

For lack of space, there is no way to meticulously describe the structure and operation of this complex system here. I rely simply on the brief introduction of those aspects which are essential for the interpretation of our topic.

\footnotetext{
${ }^{7}$ Anthropologists doing research in Mexican Indian communities often dichotomize private and public rituals (Dow 1990:14-15). The Pre-Hispanic notions and supernatural beings of kostumbre are more closely tied to the shamanic rituals, which are now mainly carried out in a family setting. Examples include the majority of fertility and healing rituals, which are directly associated with the reproduction of the individual and his environs. In the case of community rituals, however, large, public community celebrations associated with the Catholic calendar are emphasized. These are led by priests or local catechists. The shamans are only present as community members. In these festivities, the issues featured are those of collective identity and belonging to the village, in other words, of community reproduction. Their organization is closely linked to the cargo system that integrates all members of the village.
} 


\section{In 2002, the following offices were held in the village:}

\section{a. Judge and his aides}

This traditional body is of utmost importance in everyday life. Pachiquitla is today divided into three parts. In terms of production, marriage and commerce, there are no distinct rules that apply to residents of certain parts of the village. The division of the settlement is more administrative and sectoral in nature, and is intended to enable to integration of residents into offices as the village's population grows. In practice this means that each village sector developed its own separate circle of duties for its judge and his ten-person team of aides. The work of each judge is helped by the secretary and eight elected members (topil), who mainly fulfill organizing and policing roles. Among the three judges, one will rise as the most powerful, known as First Judge (juez primero). During his one-year mandate, he officially represents the village before state officials. He has the right to settle any disputes between the villagers, put someone in jail, or impose a fine.

The secretaries (or deputies) are the main aides to the judges. They organize communal labor, collect fines submitted in cash or in kind, and administer the community's finances (SZELJAK 2008). The commander and law enforcers are responsible for ensuring order in each village sector. They keep the keys to the village jail, bring disputants before the judge, and above all protect the order and prevent fights associated with alcohol consumption during celebrations.

The judges and their aides meet at least two or three times a week to consult and discuss the legal affairs of the villagers. During the meetings, the judges are required to provide coffee, brandy and cigarettes to their aides, and during the communal labor they organized, they should even provide them with food. There is also communal labor that only officials are required to perform.

\section{b. Committees}

A closer relationship with mainstream society, school education, and the emergence of various public developments in the past two decades necessitated the widening of the range of officials, requiring more and more people to perform those duties. These offices are at the bottom of the hierarchy, involve less work, and are mainly held by younger men. At the time of my research, in the village there was a Kindergarten Committee, Elementary School Lower Grades Committee, Elementary School Upper Grades Committee, Health Committee, Drinking Water Committee, and Women's Health Committee, all of which ensured the functioning of the given institution, partially secured its financial background, and mediated between the village, the teachers, as well as medical staff.

\section{c. Religious Officials}

The religious side of the hierarchy in Pachiquitla is less stratified and partly linked to organizations performing political duties. In any given year, the highest religious sponsorship belongs to the all-time judges, as it will be discussed later, but the judges' aides also have to contribute.

Church servants (fiscales de la iglesia) perform other religious duties. Every year, they elect for this post three elderly men who have lived exemplary lives and have held the post of judge. Their duty is to clean the village chapel and to secure candles and other ceremonial objects. They ring the bells, open and close the village chapel. If a priest or a missionary 
arrives in the community, church servants provide them with food and accommodations. During celebrations or processions, they often host musicians and dancers.

The Catholic priest serving the district lives in Xochiatipan, which is two and a half hours walking distance, and only gets to the village a couple of times a year. He is locally represented by a few young catechists, but they do not belong among the elected officials.

\section{d. Council of Elders}

Every villager who has held the post of judge can become a member of the Elders' Council (consejo de ancianos). Although the role of the council declined after the land wars of the 1970-1980s (SCHRYER 1990), it still retained a kind of advisory position. The council, usually assembling men over fifty or sixty years of age, has been adapting to past practices of a closed, self-sufficient community until the turn of the millennium because of its standard-setting and approach. Upon the start of his mandate, a judge selects five aides from this council, whose opinions he relies on in his work and whom he must periodically feed. One of the most important duties of the Council of Elders is that every year on November 3, they record the liabilities of the former judges and make recommendations on the following year's judges.

\section{e. General Assembly}

The General Assembly (asamblea general) is open to all heads of households over the age of eighteen. This is where they discuss government programs, labor, the schedule of joint actions, issues and events affecting the village. The Council of Elders selects officials from among them. However, the proposals must now be approved by the General Assembly as well. The General Assembly debates are done in the Nahuatl language. At these meetings, often lasting well into the night, everyone has the right to explain their views, even at length.

\section{f. Ejido Officials}

Land-owning men have to serve on the Ejido Council (comisariado ejidal), set up according to public agrarian laws, as well as on the Supervisory Board (consejo de vigilance), although it is partially independent of the cargo system. Members of the Ejido Council, elected for three years, watch over the village boundaries and properties under the leadership of the comisario. In Pachiquitla, the leader of the council can be an experienced man that has been a judge. They register changes, cultivators of individual parcels, inheritance, they resolve minor disputes among the villagers concerning land, and they can also organize communal labor. In disputes with adjacent villages about land, they represent the village before the Agrarian Court.

In 2002, some seventy men and six women held some major or minor office. Although the number of committees can vary over the years, an adult man can hold up to eight or ten positions during his lifetime. The sequence of offices is not rigidly defined, but the general perspective is that young people first serve on the different committees, then they become aides to the judge, or lower-ranking officers on the ejido, and after having held these respective offices, they may become judges and enter the Elders' Council.

The system is also known in the literature as prestige hierarchy. The higher a post, the higher the social recognition, while also requiring more financial contributions. 
State employees working in the village who are from elsewhere (doctors, medical staff, teachers) are not considered members of the village, and outside of their areas of expertise they have little say in decisions affecting the village. They have no right to attend the General Assembly, to own land or build a house in Pachiquitla. Except for school-related celebrations, they rarely take part in community celebrations. A typical example: in 1996, primary school children visited the judge and his aides - paying them the usual respect, i.e., bringing brandy and cigarettes as gifts - because someone was stealing at school. They thought that this was a problem for the village leaders and did not fall within the jurisdiction of the teachers.

The officials are not functionaries experienced in administrative or management practices, just simple peasants. It often happens that the village judge undertakes seasonal wage labor on the land of a neighbor or relative who is not an official. Even the judicial office does protect one against violations of community rules and the principle of equality. In 1998, on the feast of the patron saint of the village, one of the sponsoring judges was jailed by his own aides because he did not respect the village and incited a drunken brawl. In 1999, another judge ended up in the same place because he did not honor his duty, i.e., he did not give respect to his aides, he did not give them food, coffee, brandy and cigarettes after the nightly meetings and communal labor.

Commitments impose responsibilities upon the whole family. The whole family participates in the production and preparation of the foods and drinks offered, and in the case of a higher office, a head of household may often depend upon the financial and physical help of his older sons.

\section{OFFICIALS AND RELIGIOUS HOLIDAYS}

In any given year, the judge and his aides are not only responsible for managing the affairs of the village, but also for liaising with supernatural beings and ensuring the spiritual safety of the community. The method of their inauguration in the village also marks this, as I observed during my fieldwork. On January 16, 1999, at the administrative center, the judges received from the district political chief the command baton (baston de mando), an ornamented insignia symbolizing their authority, which indicated that the Mexican government recognized them as village leaders as well as intermediaries between the village and the Mexican government. That evening, past officials created a symbolic, arched gate at the entrance of the village made of cane, leaves and flowers. It was similar to the one they set up for the Day of the Dead altars. The arch connects the terrestrial and celestial worlds, and beneath it a sacred space is created. After they returned from the district center to the village through the mountain paths, the new judges and their aides indicated their arrival by setting off fireworks. They stopped outside the arch representing the village boundary, while the past officials and the assembled village residents were seated inside with the musicians. The shamans standing under the arch then lit the copal incense. The new judges were ritually cleansed, supernatural beings were asked to assist in their work, and ceremonial musical instruments were sounded. Finally, the past officials presented the new ones with flower crowns, garlands, brandy and refreshments under the arch. As they passed under the arch, they symbolically took over the management of the village. From here they proceeded to another sacred space, 


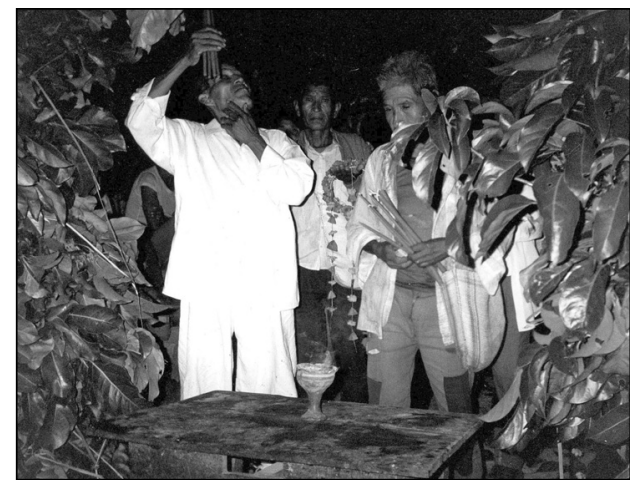

Figure 3. Ritual cleansing of the new cargo holders by the village shamans, Pachiquitla, 1999. (Photo by György Szeljak)

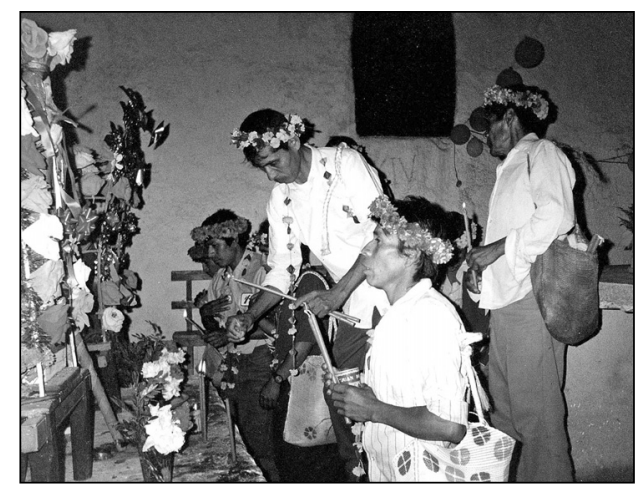

Figure 4. The new cargo holders light the candles sanctified by shamans and pray at the church altar. Pachiquitla, 1999. (Photo by György Szeljak)

the village chapel. Here the shamans and the new judges knelt before the altar and prayed, the latter also lighting the candles which the shamans handed them under the arch. Subsequently, the local catechist representing the Catholic Church greeted them, and with his leadership, together they prayed that the officials may perform their duties well. The judges then recounted what they wanted to do for the village, and they began their year-long mandatory sponsorship duties, offering all villagers biscuits and coffee at the chapel, and later at their house also food, coffee and brandy.

The judges lit candles on their home altars every day, and at regular intervals they called a shaman to pray for the village there. Until the second half of the eighties, it was also their task to summon all shamans in the area in case of extreme drought during one of the important periods of corn maturation (June - July), who would then hold a seven-day rainmaking ritual in the village chapel and on the tops of the surrounding sacred mountains.

The religious sponsorship of the officials is continuous throughout the year. Among the major occasions for food and beverage offerings are New Year's Day, the judges' Inauguration Day (January 16), Easter, Finding of the Holy Cross Day (May 3), the village patron's feast day (June 27-29), and Our Lady of Guadalupe Day (December 12). Of these, the biggest financial investment is required by the holiday of the village's patron saint, St. Peter, which is sponsored by the judges themselves. This is the most important feast day in the village, when those working in the city come home, priest arrives, children are baptized, and many get married on this day as well. Groups of young girls (virgencitas), men, as well as dancers from other villages dance for days in the church before the statues of the saints. After the procession, the saints are brought out of the chapel, a wreath of flowers is placed on their heads, and under St. Peter's leadership, they are taken through the village. They stop at the well, and the statues of St. Peter and St. Paul are dampened with flower petals immersed in water so that they could "work and not parch," provide rain, and watch over the villagers. For three nights, fireworks are held in their honor. The idea is similar to the fertility and healing rituals addressed to Pre-Hispanic supernatural beings (SzELJAK 1997; 2003). According to ritual exchange, this periodically repeated hospitality is a way for the villagers to express their respect and give thanks to the saints for taking care of them and supporting them. 


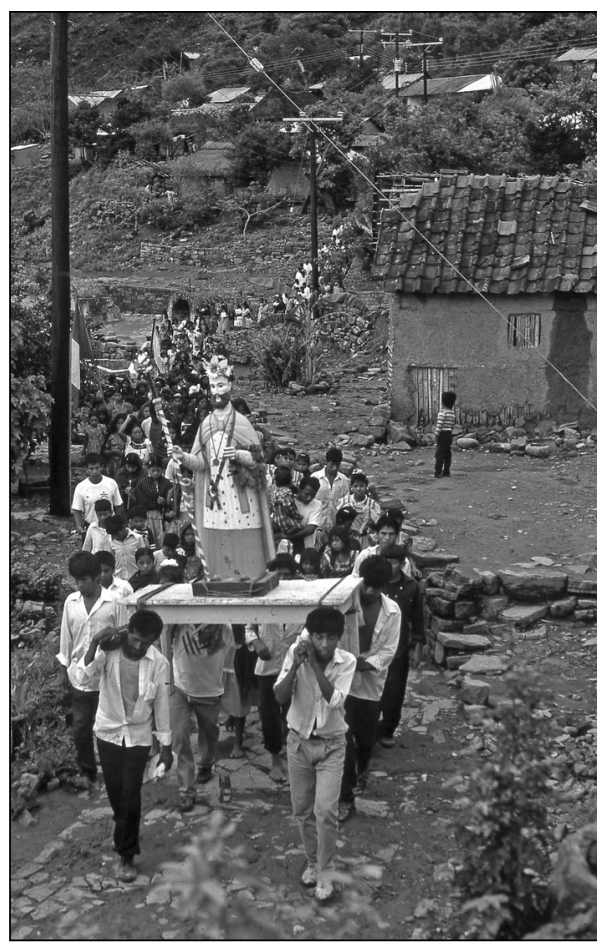

Figure 5. Procession at the Patron Saint's Day celebration, Pachiquitla, 1999. (Photo by György Szeljak)

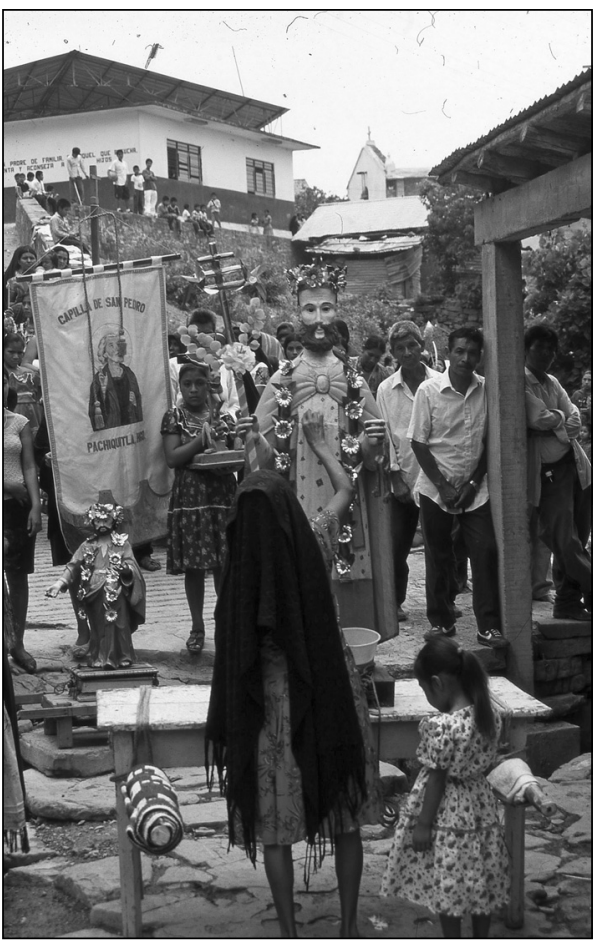

Figure 6. St. Peter's statue is sprinkled with water at the well to ensure his strength to work for the village, Pachiquitla, 1999. (Photo by György Szeljak)

Up until 1996, the judges hosted for six days (at that time all three judges got two days each), since then they host for three days all those villagers who visit them at this time, as well as the appointed members of the Elders' Council, and the visitors and dance groups coming from other villages (food, brandy, coffee). Additionally, they must pay the musicians playing during the feast, such as the traditional "huastec trio" from another village, and since the mid-nineties (since there is electricity in the village), even a young ranchero band. To ensure a festive consumption, at the three-day celebration in 2002, each judge may have spent up to 4,000-5,000 pesos (cca. 400-500 USD), if you count the market price of their own plants and animals used to prepare the food. The annual costs of the judges may have even doubled, although they tried to cover some of the expenses with plants produced by themselves, and part of the alcohol provided to their aides came from the brandy collected as penalties (SzELJAK - VAN'T HoOfT 2008). It should be noted that a village day laborer earned $45-50$ pesos with eight hours of work at this time. The majority of the judges could only cover this amount after many years of saving, from the salaries earned by their children working in cities, perhaps with the help of state child support, or with a loan. The office of judge is therefore not as popular as one might think. The term "everyone must suffer" accurately describes the attitude of the locals in the annual election of judges. The judicial office is a station in life that is 


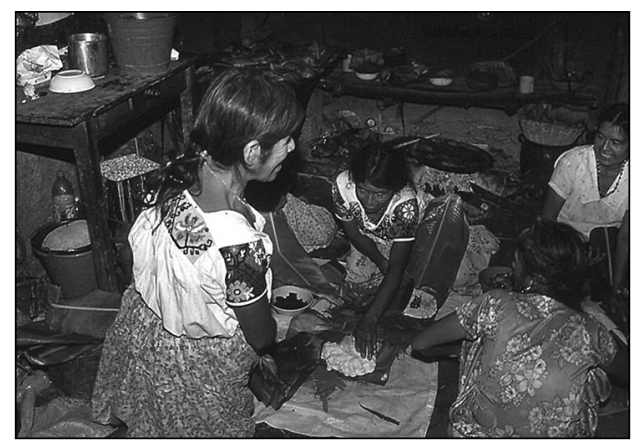

Figure 7. The jugde's relatives prepare tamal, the traditional festive food for the Patron Saint's Day celebration, Pachiquitla, 1999. (Photo by György Szeljak)

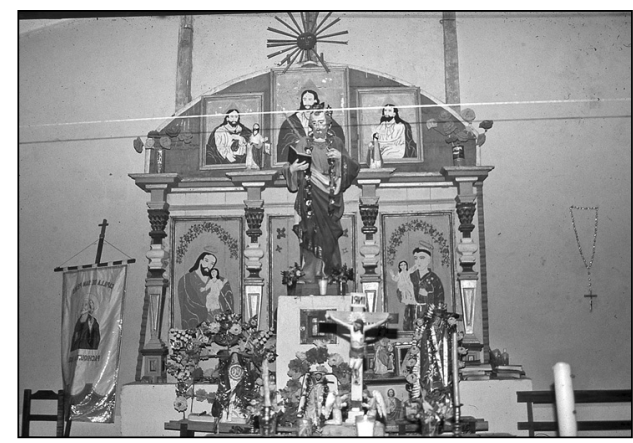

Figure 8. The church altar, Pachiquitla, 1999. (Photo by György Szeljak)

based on the community's idea of equality, is required and demanding, mandatory and very prestigious, but it does put a heavy financial burden on families. ${ }^{8}$

All healthy and married adult males have a theoretical obligation to accept the judicial office, regardless of the financial background of their family. In the case of the men serving as judges between 1996 and 2002, I did not notice that the village had any particular regard for the size of their house or land. The position was filled on the basis of the "principle of equality". All they could do was defer the request for a couple of years.

This celebration is symbolically the culmination of the decades-long official work of the judges. They are the hosts of the celebration catering to the saints and members of the village. A judge's perception depended on how successfully he represented the village's problems before the State Administration, as well as how well he catered to the guests at the village feast. When asked about their time as a judge, their reply usually highlighted what they contributed to the development of the village in a given year, as well as how much they spent on the feast of the patron saint.

The cargo system is therefore a service, a way of expressing respect for the village and the supernatural. To go through the hierarchy, and then, as a judge, to sponsor the celebration of the patron saint, is the culmination of a traditional Pachiquitla man's lifetime, a mirror of a full life. As the holiday affects the whole family, it is also a recognition for his wife and children.

In Pachiquitla, the cargo system is built upon the principles of egalitarian ideology which emphasize reciprocity and distribution. These principles are embedded in both

\footnotetext{
${ }^{8}$ In contrast to the well-studied Chamula or Zinacantán system, e.g.: CANCIAN 1976, in Pachiquitla the post requiring the largest financial contribution is not voluntary, and it is not filled from a "waiting list" because of too many applicants. The reason for this is sure to be found in the situation of the noted villages. Wasserstrom demonstrated through ethno-historical sources from Chiapas that the elaborate religious cargo system and the voluntary "fiesta sponsorship" developed in Indian areas that were nearby regional political and economic centers, and as corn and cattle farmers or wage workers, they have been connected with these regional and national centers and were thus more socially stratified (WASSERSTROM 1983). For those living in Pachiquitla, these economic integration opportunities were not available until the last decade of the $20^{\text {th }}$ century.
} 
social and ritual practices. Over their lifetime, in their minor offices, community members helped the community solely through their labor. However, they did share in the ritual offerings made by other judges and the benefits of feast sponsorships, be it ritual food and drink distribution, or harmony with the saints. By the principles of reciprocity, this is what they are repaying to the community during their judicial mandate. In this sense, the individual is part of a symbolic community which includes everyone who has ever lived and still lives in the village. References to this symbolic unity are often emphasized in the prayers shamans offer during community celebrations (SZELJAK 2008:210-211). In certain villages of the district, for example in Ohuatipa in 2002, the tradition of electing officials in the cemetery was still practiced, while in Pachiquitla this is done in the community center.

\section{NEW PROTESTANTS IN PACHIQUITLA}

One of the strongest ideological effects among modernizing Mexican Indian communities in the second half of the $20^{\text {th }}$ century was brought on by Protestantism, particularly Pentecostal denominations. Charismatic Pentecostal congregations originating in the United States started to gain success in predominantly Catholic Mexico in the 1970s. They won believers mainly in regions inhabited by Indians and among impoverished urban populations, and their religious expansion continues unabated ever since. ${ }^{9}$ The less hierarchical and centralized organizational structure, a commitment to active proselytizing, and a desire to create their own congregation prompts many missionaries to reach the farthest, most marginal regions, which provides these denominations with a unique dynamic.

Until 2002, in Pachiquitla there were about 45-50 people who were members of two Pentecostal congregations. They had not built a church of their own but met two or three times a week in private houses that had part of it converted into a tabernacle. The gatherings were not limited exclusively to members of the village; sometimes others from the nearby settlements also came for the evening prayers.

Conversions had a number of reasons. One of the first families to convert did so as a result of a miraculous healing. In many conversion stories the chief motivation was the alcoholism of the husband, which affected the whole family. But belonging to a religious community also created a new opportunity to build social networks necessary for urban migration and successful integration. The arrival of Pentecostals had an increasing impact on the life of the village; it became a matter of debate as to how non-Catholics were to relate to the community ethos and to the specific features of the cargo system.

\footnotetext{
${ }^{9}$ Higher rates of population growth among Mexican Protestants can be observed particularly from 1970. While in 1970 only $2.3 \%$ of the population considered itself Protestant, in 2000 it was $8 \%$ of those over the age of five. James Dow's quantitative comparative research shows that Protestant expansion that accelerated from 1970 to 1990 did not gain ground primarily among the urban middle class but rather in marginal areas. Mostly in federal states with a significant number of Indian populations (Dow 2001:7-10). Garma came to a similar conclusion. Based on a comparative analysis of the statistics, he states that in the country's districts where the proportion of the Indian population exceeds $70 \%$, i.e., those that are considered "Indian districts", the Protestant ratio among the population over the age of five reaches $9.89 \%$ (GARMA 2001:60).
} 
"We believe in the living God, whereas they believe in the paintings and sculptures of their saints. But they decay, they break, there is no power in them," described the situation one young convert. The believers considered the religious feasts and processions of the village to be idolatry. It was forbidden for them to go to the Catholic Church, which is the main venue for community festivals and feasts, as well as to dance and consume alcohol at these celebrations.

From a New Protestant point of view, the Catholic holidays were about pointlessly wasting the judge's fortune or the money of the other officials contributing to the festivities. If the saints do not exist, the festivals in their honor are useless, idolatrous rituals. The time "wasted" during the celebration could also be spent working instead. "Why hold so many festivals, they're just wasting their money, getting drunk, that's how they honor their saints, rather than living a sober life and working" was the New Protestant criticism of the Catholic religious holidays in the village.

In the religious sense, local New Protestants questioned at once the cult of saints as well as the shamans' ritual activities. They transformed the system of the relationship with the supernatural, and used the concept of reciprocity in a different sense. Mediation between man and God is not necessary; divine grace and support is not dependent upon ritual offerings of food and drink. Continuous prayer to God, spiritual devotion, and the realization of a moral life to His liking are enough. At the same time, a focus on individual goals, entrepreneurship, amassing material goods and prosperity are not to be condemned, but rather a sign of divine providence.

With the appearance of the Pentecostal denominations, the more unambiguous signs of belonging to the village community have become uncertain. They formed a new group with powerful symbolic boundaries. They maintained close relationships with those of similar faith living in other villages, and met with them frequently. Solidarity relations were increasingly established between those belonging to a religious community, and previous contacts, based, for example, on kinship ties, became overshadowed among those of different faiths.

This separation within the village and classification based on religious affinity is also reflected in the use of the word "hermano" (brother). Among New Protestants, this was a category of group belonging that was general, independent of denomination, a way of addressing each other. However, Catholic villagers used it in a stigmatizing, pejorative sense.

For Catholics, the biggest issue became: how to preserve the village's unity in the process of Protestant conversion? Is it even possible? Can a New Protestant man elected for important offices if he does not believe in the saints? How can this problem be solved when participating in the cargo system is mandatory, and one can only be considered a full member of the village - own a house and land, send his children to the local school - if one serves in it? And how can further conversions even be prevented?

In 1998, the village first elected a judge that recently converted to New Protestantism because of his alcohol problems. He solved the problem simply by returning to his Catholic faith under community pressure. Others were elected to only minor offices until 2002. In their case, a compromise was reached that they had the right to stay away from the Catholic celebrations but could not openly criticize them in their official position. The villagers tried to find a kind of compromise. The New Protestants were considered full members of the village but they could not forcefully proselytize, and they could 
not use the village's public spaces for their rituals. As they were often relatives and close acquaintances, the village was trying to maintain the unity of the community in spite of religious differences, and the question of collective identity surpassed religious commitment. For example, New Protestant men participated in communal labor related to Catholic celebrations and in fundraising, even though they were absent from the religious part of the celebration. Most families also contributed to the costs of the fireworks set up for the feast of the patron saint, notwithstanding its connection to a Catholic holiday. The relationship was not entirely harmonious, but there were no open clashes for a while. However, in 2001, the first major conflict erupted.

\section{“WE DO NOT WANT A PROTESTANT CHURCH!"}

A respected widow lived near the main square with her father. Her son was still young when he moved to the city more than ten years before the incident, and over time he became the pastor of a Pentecostal congregation; eventually he converted the members of his family who stayed behind. As long as he only came back to visit, no one in the village objected. I met him several times during my fieldwork. He vehemently criticized the ignorance of the locals, and enthusiastically talked about the faith that changed his life. However, in 2001 he decided to return home permanently and build his own house on the plot once allocated to his parents. This plot was located near the main square, directly opposite the Catholic chapel. Catholics living in the village suspected that the house would also become a tabernacle, and his return would set off a forceful proselytizing movement in the village; it might not be possible to find the same compromise with him as with other converts. They also feared that the central location of the tabernacle would symbolically divide the main square as well. This was not just mere rivalry, but the ritual fear of followers of a syncretistic religion incorporating Pre-Hispanic imagery that the construction of a tabernacle would threaten the goodwill of supernatural beings.

The Catholics began to organize, the uproar increased, and they demanded a decision from the village leaders. Meanwhile, the pastor quickly began to build a simple, traditional house on the property, hoping that if he built it, the village would be powerless to do anything. The house had been completed, the sides were covered with reed, the roof had been raised, crops had been planted, and only the mud plaster was left to do.

The village did not take the case before the state court, because they thought that in this case, the local judge had the right to decide. He eventually ordered the demolition of the house, which the local Catholics quickly implemented. The plot of land was seized as part of a symbolic expropriation for the benefit of the community, and they very quickly built a stone building in its place that has since been used as teachers' quarters.

The underlying basis of the argument for the demolition of the house was that the village has an "internal law". It may not match the Mexican Civil Code provisions in this regard, but the village's internal, common laws override all of it. According to this, only he can be a member of the village and build a house there who regularly takes on an office in the community, and with weekly communal labor continuously contributes to the village's investments in infrastructure (installing electricity, constructing community buildings, maintaining roads and trails, reinforcing the hillside against landslides with retaining walls, bringing drinking water from a remote river), or pays fines to redeem 
himself. All this they wanted the man to pay for, but they imposed a fine of such an unusually large sum that they did not expect the man would be able to pay it. The core of their argumentation was thus not the open expulsion of New Protestants but compliance with the village's internal laws, the principle of equality.

Although the man took the matter to the state court - which was still ongoing during my last visit in 2002 - but left the village after the incident. Interviews about the matter revealed that, as in so many cases, both sides tried to condense into the concept of respect the system of moral rules which proved their truth. For the Catholics, this meant respect for the supernatural and recognition of the village's common laws. For the evangelist, it meant free religious exercise and the sanctity of personal property, as well as the supremacy of state institutions over the local cargo system.

\section{SUMMARY}

This study sought to answer how Pachiquitlans tried to demarcate the village community around the turn of the millennium, and what role the cargo system played in this. As Govers notes, in Mexican Indian villages, community is not considered inherent; it must be created and maintained continuously through cultural practices (kinship relations, exchanges, festivals, rituals, communal labor, collectively accepted legal customs, etc.) and through the debates over them, amid the challenges of modernization (Govers 2006:8-12).

In Mexico, the spread of Protestantism is most intense in the Indian regions where subsistence and other forms of amassment linked to market economy, such as wage labor, gained an increasingly more significant role in the formerly self-sufficient communities, and where the villages are becoming more open and migration is affecting an increasing proportion of the population. New lifestyle patterns are emerging, and everyday thinking incorporates elements that increasingly emphasize individual and family prosperity to the detriment of community traditions. Conversion in these villages may also be prompted by the fact that it can discharge them from the obligation of the sponsorship of Catholic celebrations. However, these processes are associated with new ideas about the creation of community and locality (APPADURAI 1996), and the establishment of solidarity relations, which could lead to changes in the village's cargo system. One solution is the secularization of the system, when religious tasks and the financial sponsorship associated with them are separated from the cargo system, and they become the internal matter of each individual denomination. At other times, the Indian villages become daily battlegrounds of religious disputes and clashes, and in extreme cases, members of one sect try to drive out of the village members of another sect - for which there are also many examples in Mexico. All these conflicts surface parallel with the generational challenges affecting the system, in which the power and decisions of older officials who have reached a higher position in the hierarchy are being questioned by the younger people who have experience in urban migration, speak Spanish better, and belong to various Mexican political parties. But this is already part of a different story. 


\section{REFERENCES CITED}

APPADURAI, Arjun

1996 Modernity at Large. Cultural Dimensions of Globalization. Minneapolis: University of Minnesota Press.

CÁmara, Fernando

1952 Religious and Political Organization. In TAx, Sol (ed) Heritage of Conquest. The Ethnology of Middle América, 142-173. Glencoe: The Free Press. (Viking Fund Seminar on Middle American Ethnology.)

Cancian, Frank

1976 Economía y prestigio en una comunidad maya [Economy and Prestige in a Maya Community]. México: Instituto Nacional Indígenista.

CARRasco, Pedro

1976 La jerarquía cívico-religiosa de las comunidades mesoamericanas. Antecedentes prehispánicos y desarrollo colonial [The Civil-Religious Hierarchy in the Mesoamerican Communities. Prehispanic Backgrounds and Development in the Colonial Period]. Estudios de Cultura nahuatl 12:165184.

CARrera Q., Sergio E.

2007 A son de campana. La fragua de Xochiatipan [The Sound of Bell. The Forge of Xochiatipan]. México: Centro de Investigaciones y Estudios Superiores en Antropología Social - El Colegio de San Luís Potosí - Universidad Autónoma del Estado de Hidalgo.

Chenaut, Victoria - Sierra, María T. (eds)

1995 Pueblos indigenas ante el derecho [Indigenous Villages Before the Law]. México: Centro de Investigaciones y Estudios Superiores en Antropología Social - Centro de Estudios Mexicanos y Centroamericanos.

Contreras V., Jessica Itzel

2008 "Aqui la gente es buena y mala, pero con razón." Costumbre jurídica en Coachumo ["The People Here Are Good or Bad, but Rightly So." Customary Law in Coahumo]. BA thesis, ENAH, Mexico D. F.

Dow, James W.

1990 Santos y supervivencias [Saints and Survival]. México: Consejo Nacional para la Cultura y las Artes Instituto Nacional Indigenista.

2001 Protestantism in Mesoamerica. The Old Within the New. In Dow, James W. SANDSTRom, Alan R. (eds) Holy Saints and Fiery Preachers. The Anthropology of Protestantism in Mexico and Central America, 1-23. Westport, CT: Praeger.

Dow, James - STEPHEN, Lynn (eds)

1990 Class, Politics, and Popular Religion in Mexico and Central America. Washington, D.C.: American Anthropological Association.

FRIEDLANDER, Judith

1982 The Secularization of the Cargo System. An Example from Postrevolutionary Central Mexico. Latin-American Research Rewiev 16(2):132-143. 
Garma N., Carlos

2001 Religious Affiliation in Indian Mexico. In Dow, James W. - SANDSTROM, Alan R. (eds) Holy Saints and Fiery Preachers. The Anthropology of Protestantism in Mexico and Central America, 57-72. Westport, CT: Praeger.

Govers, Cora

2006 Performing the Community. Representation, Ritual and Reciprocity in the Totonac Highlands of Mexico. Berlin: LitVerlag.

GreEnBERG, James

1981 Santiago's Sword. Chatino Peasant Religion and Economics. Berkeley: University of California Press.

Sandoval F., Eduardo A. - Topete L., Hilario - Korsbaek, Leif (eds)

2002 Cargos, fiestas, comunidades [Positions, Feasts, Communities]. México: Universidad Autónoma del Estado de México.

SCHRYER, Frans J.

1990 Ethnicity and Class Conflict in Rural Mexico. Princeton: Princeton University Press.

SzELJAK, György

1997 Curación e identidad. Algunos aspectos de la religión nahua en la Huasteca Hidalguense en el Municipio de Xochiatipan [Healing and Identity. Some Aspects of Nahua Religion in the Huasteca Hidalguense, Municipality of Xochiatipan]. Acta Hispanica 2:29-41.

2000 Az összetorlódott idő. Tradíció és modernizációs változások egy mexikói indián közösségben [Accumulated Time. Tradition and Modernization in a Mexican Indigenous Community]. In Fesős, Zoltán - TASNÁdI, Zsuzsa - SzELJAK, György - GranaszTói, Péter (eds) A megfoghatatlan idö [The Intangible Time], 118-135. Budapest: Néprajzi Múzeum. (Tabula Könyvek 2.)

2003 “... porque si no comemos maíz no vivimos”. Religión e identidad en la Huasteca hidalguense [“...Because If We Do Not Eat Corn, We Won't Live." Religion and Identity in the Huasteca Hidalguense]. In PÉREZ Z., Juan M. Ruvalcaba M., Jesús (eds) Viva la Huasteca. Jóvenes miradas sobre la region [Viva la Huasteca. The Region from Young Researchers' Perspective], 113144. México: Centro de Investigaciones y Estudios Superiores en Antropología Social - El Colegio de San Luis.

2008 “Tisztelnünk kell egymást”. Nahua világkép és kulturális változások Pachiquitlában a 20. század végén ["We Have to Respect Each Other." Nahua Worldview and Cultural Changes in Pachiquitla at the End of the $20^{\text {th }}$ Century]. PhD thesis, Szegedi Tudományegyetem. http://doktori.bibl.uszeged.hu/1238/1/SZELJAK_GY\%C3\%96RGY PHD.pdf (accessed June 24, 2016)

2013 Tisztségviselői rendszer, vallás és a közösségbe tartozás vitái egy indián faluban [Cargo System, Religion and Debates about Community Inclusion in an Indigenous Village]. In SzÁsz, Antónia - KIRZSA, Fruzsina (eds) Kultúrakutatás és narratíva. Tanulmánykötet A. Gergely András tiszteletére 60. születésnapja alkalmából [Research on Culture and Narratives. Studies in Honor of András Gergely's 60 ${ }^{\text {th }}$ Birthday], 215-229. Budapest: MAKATL'Harmattan. 
SzelJaK, György - VAN'T Hooft, Anuschka

2008 Consumo del alcohol y modernización en Pachiquitla, Mexico [Alcohol Consumption and Modernization in Pachiquitla, Mexico]. In Espaciotiempo. Revista Latinoamericana de Ciencias Sociales y Humanidades 1(1):56-72.

WASSERSTROM, Robert

1983 Class and Society in Central Chiapas. Berkeley and Los Angeles: University of California Press.

György Szeljak PhD, studied history and Hispanic studies at the JATE, Szeged and cultural anthropology at the ELTE, Budapest. He conducted fieldwork in Mexico between 1996 and 2002. He has been working at the Museum of Ethnography in Budapest since 2000; he is currently the curator of the America Collection. He specializes in Mexican Indian cultures, interethnic relations, migration issues and also gives university lectures on the anthropology of Latin America. Email-address: szeljak@neprajz.hu 